\title{
A Systems Analysis of the Development Status and Trends of Rural Household Energy in China
}

\author{
Min He ${ }^{1}$, Pei Liu ${ }^{1}$, Linwei Ma ${ }^{1,2, *(\mathbb{D})}$, Chinhao Chong ${ }^{1,2}{ }^{\mathbb{D}}, \mathrm{Xu} \mathrm{Li}^{1,2}$, Shizhong Song ${ }^{1}$, \\ Zheng $\mathrm{Li}^{1,2}$ and Weidou $\mathrm{Ni}^{1}$ \\ 1 State Key Laboratory of Power Systems, Tsinghua-BP Clean Energy Research \& Education Center, \\ Department of Energy and Power Engineering, Tsinghua University, Beijing 100084, China; \\ mina23805@163.com (M.H.); liu_pei@tsinghua.edu.cn (P.L.); zhangjinghao@126.com or \\ zjh08@tsinghua.org.cn (C.C.); tsinghualx1994@163.com (X.L.); ssz777777@163.com (S.S.); \\ lz-dte@tsinghua.edu.cn (Z.L.); niwd@tsinghua.edu.cn (W.N.) \\ 2 Tsinghua-Rio Tinto Joint Research Center for Resources, Energy and Sustainable Development, \\ Laboratory for Low Carbon Energy, Tsinghua University, Beijing 100084, China \\ * Correspondence: malinwei@tsinghua.edu.cn; Tel.: +86-10-6279-5734; Fax: +86-10-6279-5736
}

Received: 4 June 2018; Accepted: 28 June 2018; Published: 3 July 2018

check for updates

\begin{abstract}
This paper attempts to present a complete picture of the status quo and future trends of the development of rural household energy in China based on a literature review and a systems analysis. First, a comprehensive literature review was conducted from the perspectives of energy consumption, carbon emissions and pollutants, energy resources, energy technologies, and energy policies. The review revealed the complexities and dynamics of the current system of rural household energy in China, and several key issues were identified for further attention. These issues are further explored by a systems analysis based on the "Integrated strategy of Sustainable development objectives, Decision-making systems, Operation systems, and Physical systems" (I-SDOP) concept. Following this method, a complete picture of the market status and policy targets is presented, by mapping an energy Sankey diagram and by reviewing the behavior of the main players. The results indicate that synergy of various energies, technologies, and players, and a combination of flexible engineering schemes and policy designs, with adequate consideration of temporal variation and regional disparity, are key strategies to promote the sustainable development of rural household energy, especially the distributed utilization of renewable energy, in China.
\end{abstract}

Keywords: Sankey diagram; systems analysis; sustainable development; renewable energy

\section{Introduction}

Energy poverty is still a worldwide issue, affecting 3 billion people who rely heavily on traditional fuels to meet their energy needs [1], especially in rural areas [2-5]. For rural energy [6,7], rural household energy is of great importance, since it is directly relevant to quality of life [8]. Rural household energy includes both commercial and non-commercial energy used for cooking, heating, cooling, hot water, lighting, appliances and others [9]. With a huge rural population of 589.7 million in 2016 [10], China's solutions regarding rural household energy are a crucial reference for dealing with the global challenge of energy poverty. Moreover, this is related to multiple additional urgent issues originating from $\mathrm{CO}_{2}$ emissions [8,11,12], air pollution [13-16], energy efficiency, and the use of renewable energy. Thereby, the issues associated with rural household energy use in China urgently require solutions to ensure sustainable development.

Currently there are many different opinions regarding solutions for rural household energy use in China. This leaves decision makers in government and enterprises in a difficult and 
confusing situation. The underlying reason is the system complexity involved. First, the problem involves multi-dimensional objectives, involving carbon emission reduction, energy supply security, energy poverty elimination, as well as public concerns about environmental quality and human health. Second, there exists a multi-element theme concerning the environment, technology, markets, and policy. Achieving sustainable development requires coordination among these dynamically changing elements. Third, regarding those objectives and elements, various agents like governmental departments, enterprises, and farmers represent respective and inconsistent interests. Due to these complexities, a comprehensive solution must be based on a system-wide integration of these objectives, elements, and agents. According to the literature review in Section 2, such a study on integrated strategies for rural household energy use in China is still lacking.

This paper attempts to present a complete picture of the status quo and future trends in the development of rural household energy in China, thus offering a scientific reference for policy makers and to help promote sustainable development. Based on a literature review in Section 2 and previous studies of energy strategies and energy systems [17-20], this study develops a systems method of "Integrated strategy of Sustainable development objectives, Decision-making systems, Operation systems and Physical systems" (I-SDOP) to perform a multi-objective, multi-element, and multi-agent analysis to reveal a complete picture. The methodology and data is introduced in Section 3, results and discussion are presented in Section 4, and conclusions and suggestions are summarized in Section 5.

\section{Literature Review}

Reflecting the urgency of the research on rural household energy in China, many previous studies have been published focusing on specific perspectives, including energy consumption, carbon emissions, air pollution, energy resources, energy technologies, and energy policies.

\subsection{Energy Consumption}

Previous studies have researched energy consumption in China's rural areas according to field surveys or existing statistics, some of which are listed in Table 1.

Table 1. Some studies about rural energy consumption in China.

\begin{tabular}{ccc}
\hline Data Source & Published Year & Studies \\
\hline \multirow{3}{*}{ Regional field surveys } & 2008 & Cai and Jiang [21] \\
& 2011 & Fan et al. [22] \\
& 2013 & Liang et al. [11] \\
\hline \multirow{3}{*}{ Statistical data } & 2012 & Yao et al. [23] \\
& 2013 & Zhang and Guo [24] \\
& 2016 & Zhang et al. [25] \\
\hline \multirow{3}{*}{ National field surveys } & 2017 & Hou et al. [26] \\
& 2014 & Duan et al. [27] \\
& 2017 & Wang and Jiang [28] \\
& 2017 & Wang et al. [29] \\
& 2017 & BECTU [9] \\
\hline
\end{tabular}

Coal and biomass are still the predominant energy choice in rural areas of China. Using large scale micro-survey data, Hou et al. [26] found that in 2011, $60 \%$ of rural households adopted traditional biomass resources as their main fuel for cooking. Fan et al. [22] investigated the energy consumption of rural households in two undeveloped regions and found a high dependency in rural household energy on coal and biomass (firewood or straw). A field survey of rural households covering 31 provinces [27] revealed that in 2012 , the predominant fuel for cooking was biomass $(47.6 \%)$ in rural populations, 
and in terms of heating, coal (21.4\%) and biomass (19.0\%) were the main fuels used in rural households. This finding closely aligns with another field survey of 30 rural counties in 25 provinces [28].

An obvious transition from non-commercial energy to commercial energy can be found in literature. Yao et al. [23] found that in 2001-2008, energy consumption by rural households showed an obvious transition from non-commercial energy to commercial energy. Zhang and Guo [24] found that over 1991-2010, commercial energy consumption by rural households in China grew at a yearly rate of only $2.15 \%$. However, energy consumption per capita increased by $89.21 \%$ during the same period. A study on Jiangsu Province [25] revealed that during 1995-2011, the increasing space energy efficiency effect and floor area were the main factors influencing energy demand growth in rural households.

A significant spatial divide in rural fuel choice can be observed in China. A recent field survey [29] investigated the energy consumption of 1440 rural households in 8 typical counties of 8 China's economic zones, and revealed significant differences across the various economic zones in energy consumption levels and the structure of rural households. One complete and recent data we found was in a report [9] based on a field survey of the energy consumption of rural residential buildings in 2014 of 21 provinces, and also in a former survey in 2006 of 24 provinces. This report revealed obvious spatial difference among provinces in terms rural energy use, especially between the northern and southern areas.

This literature indicates that energy consumption by rural households in China is changing dynamically, with sizable regional disparities. Although the total energy consumption of rural households is growing slowly, per capita energy consumption is increasing dramatically during rapid urbanization [30]. A transition from traditional energy, such as biomass and coal, to modern and commercial energy, such as electricity and LPG (liquefied petroleum gas), is happening widely. There are many factors influencing this transition, but the increasing income of rural households is certainly important. Meanwhile, we also found frequent data inconsistency in various research works.

\subsection{Carbon Emissions and Air Pollution}

$\mathrm{CO}_{2}$ emissions in rural areas of China have increased significantly over time. It was calculated [7] that the total direct $\mathrm{CO}_{2}$ emissions resulting from rural energy consumption nearly tripled in 1979-2008, whilst indirect emissions nearly quadrupled. Yao and Chen [23] reported that the total $\mathrm{CO}_{2}$ emissions from rural household energy consumption increased significantly over 2001-2008, with an annual growth rate of per capita $\mathrm{CO}_{2}$ emissions nearly twice as fast as that for urban areas. A case study on a typical county in Shandong Province [11] over 1980-2009 identified the increasing income of rural households and changing lifestyles as the main driving forces increasing $\mathrm{CO}_{2}$ emissions. A later study [31] found that space heating and cooling accounted for the largest proportion of emissions over 1996-2012. Liu et al. [8] proposed to shift to more efficient commercial energy, to commercialize biomass energy, and to improve the combustion efficiency of traditional biomass use. Li et al. [32] also suggested the full development and utilization of renewable energy as the key and effective solution.

Besides $\mathrm{CO}_{2}$ emissions, rural household energy consumption, particularly the direct burning of solid fuels (coal and biomass) [33] also produces a lot of air pollution, posing a severe threat to the environment and rural residents' health. The inefficient combustion of coal and biomass in China contributed $30-50 \%$ of the total anthropogenic emissions of $\mathrm{CO}$, fine particulate matter $\left(\mathrm{PM}_{2.5}\right)$, black carbon (BC), and polycyclic aromatic hydrocarbons (PAHs), and had significant adverse consequences for indoor and ambient air qualities [14]. The contributions are higher in less economically developed regions. The burning of agricultural crop residue, including open-field burning and burning as a household fuel, is a significant emission source of primary $\mathrm{PM}_{2.5}$ and the gaseous precursors of secondary $\mathrm{PM}_{2.5}$ in rural areas [34]. Rural households using solid fuel with low energy efficiency have lower levels of self-assessed health and a higher prevalence of respiratory diseases, especially for the female responsible for most of the cooking and for the children accompanying her [13]. In addition to administrative control measures from the government to 
forbid the open-field burning of crop residues, the integrated utilization of agricultural crop residue is suggested as another type of control measure [34].

The above literatures reveal the seriousness of the problem of $\mathrm{CO}_{2}$ emissions and air pollution from rural household energy consumption in China, and also the inconsistent opinions regarding solutions to reduce emissions.

\subsection{Energy Resources}

Biomass is a hot topic in the research of rural energy in China. An early study [35] estimated that, from 1995-2005, China produced 630 Mt of crop residue per year. The larger portions of the crop residues were used with low efficiency or wasted. Jiang et al. [36] used a GIS-based approach to derive the production of net available crop residues as about 505.5 Mt per year in 2009, with the bioenergy potential being about 253.7 Mtce. Meanwhile, the majority of the net available crop residues are concentrated in the two grain-producing areas, including the Huang-Huai-Hai region and the North-East Plain [36]. Qiu et al. [37] gave a higher estimation of China's total output of crop residues as $729 \mathrm{Mt}$ in 2010, in which 147-334 Mt could be used for commercial energy production. Besides, Tang et al. [38] revealed the great resource potential of forestry residue in China.

Wind, solar, and small hydro are also promising energy resources, especially in the west of China. An early study [39] estimated the resource potential of small-scale wind and solar power to meet rural livelihood needs in Inner Mongolia, Xinjiang, and Qinghai. He and Kammen [40] estimated that China's annual wind generation could reach 2000 to 3500 TWh, and Xinjiang, West Inner Mongolia, East Inner Mongolia, Gansu (onshore wind), and Jiangsu (offshore wind) each have a potential capacity of more than $100 \mathrm{GW}$ of wind power. For solar [41], they estimated a potential of stationary solar capacity of 4700-39,300 GW and distributed solar of about $200 \mathrm{GW}$ in China, while the stationary solar capacity is mostly located in north-western China in wide rural areas. For small hydro, $\mathrm{Xu}$ et al. [42] estimated there is still $60.8 \mathrm{GW}$ of small hydropower that can be further exploited as compared to the year 2010, and Sichuan, Tibet, and Yunnan in the south-western China have the greatest potential.

Therefore, it can be concluded that there are abundant renewable energy resources in rural China that can be further exploited, especially biomass resources in the east and other renewable resources (wind, solar, and small hydro) in the west.

\subsection{Energy Technologies}

The technical choice of rural household energy is a research area full of diverse and controversial views, especially for rural heating and cooking.

Energy technologies of biomass utilization are the first focus, with much discussion on improvement of traditional biomass utilization technologies like Kang systems, and assessment of modern biomass utilization technologies, such as biogas and biomass solid fuels. An early study [43] doubted the sustainability of using alternative heating methods based on commercial energy to replace the traditional heating system based on biomass, Kang, in rural north China. Meanwhile, Zhai et al. [44,45] pointed out that current Kang systems in rural China are inefficient and suggested improvements in the building envelope and the installation of room radiator water systems. For biogas, studies [46,47] found that household biogas is not a sufficient tool to eliminate low-quality fuel use. Wang et al. [48] suggested that for future biogas development, medium-to-large biogas projects should be encouraged and the reduction of household biogas projects should be allowed to continue. Besides biogas, biomass solid fuels are researched [49,50], with conclusions that the economic performance of corn straw briquette fuel is better than that of corn straw pellet fuel, and further policy support is required to make them more competitive in the market.

In the discussion of other energy technologies excepting biomass utilization, the distributed use of solar energy is also a hot topic. Zhu and Chen [51] reviewed the development of passive solar houses over 1977-2012 in rural north China, and found that its application was widespread before 2000 but almost at a standstill after that, due to the lack of professional design and indoor air temperature 
prediction methods. Shan et al. [52] pointed out that the rapid development of solar heating systems in China encountered the problems of high initial cost, low average room temperatures, and excessive auxiliary energy consumption, and that integrated systems aided by other energy technologies should be encouraged.

Overall, most of the clean and renewable energy technologies have become mature and are ready for commercialization. Tian [53] pointed out that rural biogas, energy utilization of crop straw, firewood and coal-saving furnaces, stoves and the Kang system, and heat utilization from solar energy are technically mature. However, it is still difficult for China's government to decide which technology pathway should be prioritized for developing rural household energy.

\subsection{Energy Policies}

Energy policy is a noteworthy topic as a crucial support for the development of rural household energy in China, but most previous studies took rural energy as a whole. An early study [54] mentioned that, since the reform and opening-up, China's rural energy policies have gone through three stages, including: (1) to overcome the energy shortage during 1979-1995; (2) to provide for national energy security and energy supply diversification over 1996-2006; and (3) to mitigate and adapt to climate change since 2007. Many studies agreed and referred to this study.

The main barriers in the energy policies of rural China that were identified by previous studies include:

(1) First, there is an institutional problem caused by the urban-rural divided pattern of energy management due to a dual structure of urban and rural development in China, which resulted in a lack of attention paid to rural energy development [54,55].

(2) Second, there is lack of coordination and consistency among various rural energy policies due to an incomplete policy system and a fragmented management system [12,54,55]. Central government's policy framework for the rural energy industry lacks a systematic and clear schedule, and the developmental targets for a rural energy industry can be changed easily by local governments, although initially they have been drafted by the central government of China [55].

(3) Third, there is a lack of innovation in regional renewable energy policies [56], while rural areas are the main region for the distributed use of renewable energy.

(4) Fourth, the government has worked for years on a rural building code system aimed at narrowing the energy efficiency gap between urban areas, but it is in the beginning phases [57].

(5) Finally, financial support for rural energy remains limited to government funds and subsidies as well as farmers' private investment, and high-cost rural energy projects can barely attract large commercial investment [55].

For technology innovation policies, the main directions suggested by previous studies [12,54-57] include modern biomass energy, electricity from other renewable energy sources, and energy efficiency, and rural areas have become the focus in recent policy discussions to replace distributed coal burning [55,58-60]. In general, there is lack of specific policy research on rural household energy, except that regarding building energy efficiency. Moreover, few studies can systematically integrate a bottom-up analysis of technology innovation into policy discussions focusing on rural household energy.

\subsection{Summary}

It can be concluded that there are few comprehensive studies published regarding a national strategy for the development of rural household energy in China. One of the main reasons for this is the lack of integration of various aspects, including energy resources, the environment, energy technologies, energy markets, and energy policies. Four questions are proposed for further study to identify comprehensive solutions of rural household energy in China, as follows: 
(1) What's the actual situation and complete picture of the current energy systems?

(2) What are the prioritized technology choices to improve the energy systems?

(3) How can we realize and accelerate technology innovation based on market mechanisms?

(4) How can we improve policy systems to support technology innovation?

The Chinese government has implemented some pilot projects to explore development pathways for rural household energy. According to our field survey, a large-scale biogas project supported by national finance has been implemented in Chifeng City, Inner Mongolia. The project utilizes straws collected by the company itself or local agents to produce biomethane and organic fertilizer, which will be sold to gas stations, local residents or public facilities. The biogas project runs well with good business model innovation. Another example is the promotion of flexible energy-saving stoves in a village of Chifeng City. Fuels like straw, livestock excrement, firewood and solid biofuels are available in the stoves for cooking and heating in rural households. The government provides sufficient policy and finance support. The enterprise takes charge of devices supply and installation, and technical services. Professional cooperatives are responsible for the collection, processing, production, and distribution of straw. This model will be further explored in other projects. However, these efforts are not enough to determine future pathway of rural household energy development in China. More research and exploration are still needed.

\section{Methodology and Data}

Although the aforementioned four questions can hardly be fully answered by one study, we attempt to present a complete picture of the status quo and future trends of the development of rural household energy in China, as a reference to solve the problems. A framework and procedures for systems analysis are developed to reveal the internal mechanisms of the underlying complex system with multi-objectives, multi-elements, and multi-agents.

\subsection{The Integrated Strategy of Sustainable Development Objectives, Decision-Making Systems, Operation Systems, and Physical Systems (I-SDOP) Concept}

The methodology of this study is based on the I-SDOP system concept, developed from previous systems analysis regarding strategic and policy issues for the development of national energy [17,18,61,62], oil [19], coal [63], NG (natural gas) [64], iron ores [20], and provincial energy [65].The I-SDOP concept (as illustrated in Figure 1) generally describes complexities involved by strategic research on regional energy systems as follows:

(1) The whole system is composed of three sub-systems, including Decision-making systems, Operation systems, and Physical systems, and is constrained by Sustainable development objectives decided by the surroundings.

(2) With pre-determined political wills respecting Sustainable development objectives, the Decision-making systems make strategic plans and policies, and propose demonstration projects to promote the Operation systems consciously pursuing the political will.

(3) With specific market rules shaped by policies, the Operation systems give daily operations to the Physical systems, including research and development, construction, operations and maintenance, and retrofit and retirement, following the respective values and benefits of various operators (stakeholders) to reach a market equilibrium.

(4) Decided by an energy balance, the Physical systems forms energy flows from energy sources through energy conversion to the end-use of energy, providing energy services to the Operation systems, and also generates environmental emissions that will impact the Sustainable development objectives.

(5) The dynamics of the whole system are influenced by the behaviors of the three sub-systems and their interactions. Moreover, there is always more than one decision-maker, more than one market 
operator, and more than one technical stage in the Decision-making systems, Operation systems, and Physical systems, respectively.

Based on the above considerations, a systems analysis based on the I-SDOP concept can possibly realize a cross-disciplinary study taking into account both the system complexities of multi-objectives, multi-elements, and multi-agents.

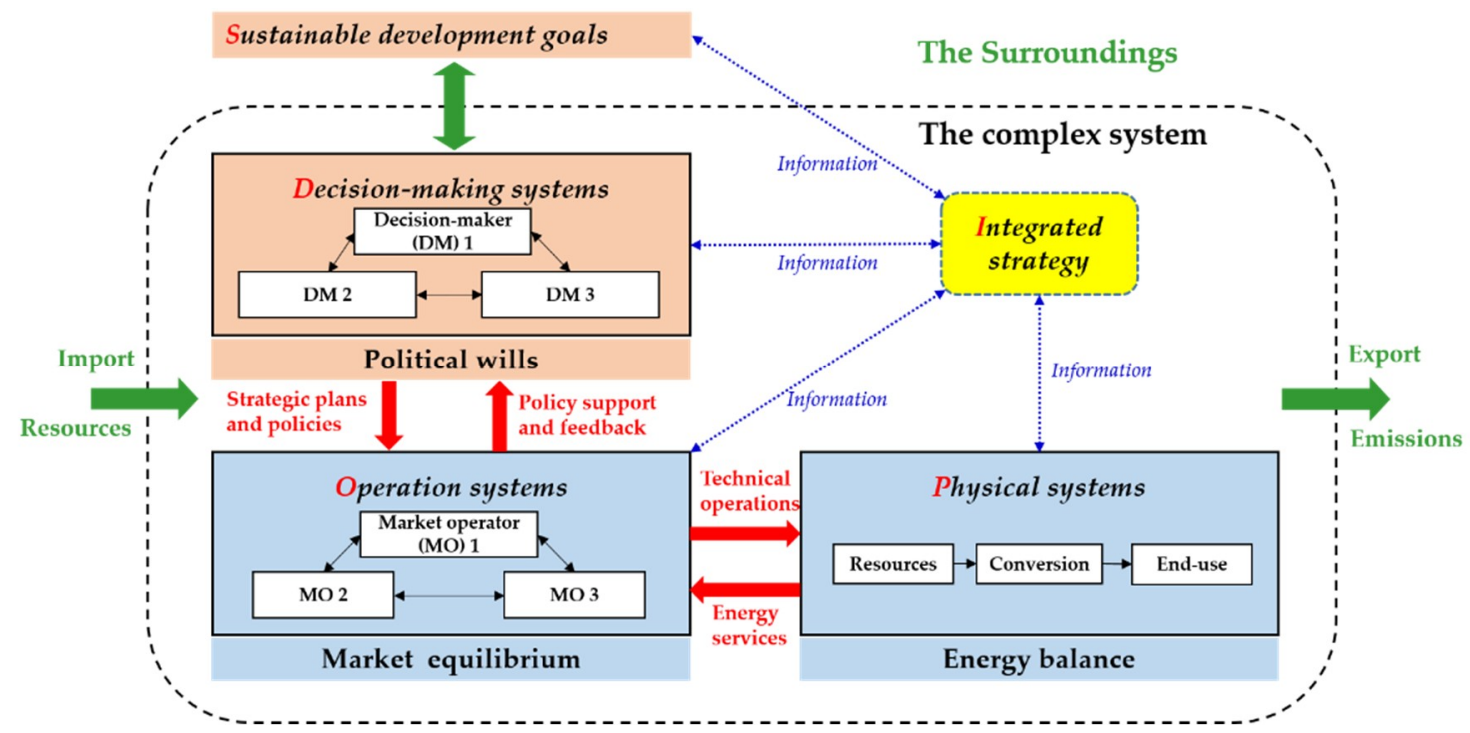

Figure 1. An illustration of the Integrated strategy of Sustainable development objectives, Decision-making systems, Operation systems, and Physical systems (I-SDOP) concept.

\subsection{The Systems Analysis Methods}

Although the I-SDOP concept is quite complex, in order to carry out a practical analysis based on available data, the method is limited to three steps as shown in Table 2. The detailed introduction of systems analysis methods are as follows.

Table 2. Main content and methods of the three steps in the I-SDOP analysis.

\begin{tabular}{|c|c|c|c|c|}
\hline Step & Content & & Methods or Tools & Results or Output \\
\hline \multirow[t]{3}{*}{1} & \multirow{3}{*}{$\begin{array}{l}\text { Market } \\
\text { status }\end{array}$} & $\begin{array}{l}\text { (1) Rural household } \\
\text { energy structure }\end{array}$ & Sankey diagram & $\begin{array}{l}\text { Energy allocation Sankey } \\
\text { diagram of China's rural } \\
\text { households in } 2014\end{array}$ \\
\hline & & $\begin{array}{l}\text { (2) Market operator } \\
\text { behaviors }\end{array}$ & $\begin{array}{l}\text { Statistical review and } \\
\text { qualitative discussion }\end{array}$ & $\begin{array}{l}\text { Status and trends of rural energy } \\
\text { demand, centralized energy } \\
\text { supply and end-use services }\end{array}$ \\
\hline & & $\begin{array}{l}\text { (3) Dynamic } \\
\text { market evolution }\end{array}$ & Qualitative discussion & $\begin{array}{l}\text { Three stages of rural energy } \\
\text { market development }\end{array}$ \\
\hline \multirow{3}{*}{2} & \multirow{3}{*}{$\begin{array}{l}\text { Policy } \\
\text { targets }\end{array}$} & (1) Long-term goals & $\begin{array}{l}\text { Literature review and } \\
\text { qualitative discussion }\end{array}$ & $\begin{array}{l}\text { Sustainable development goals } \\
\text { for rural household energy }\end{array}$ \\
\hline & & $\begin{array}{l}\text { (2) Mid-term } \\
\text { objectives }\end{array}$ & Policy discussion & $\begin{array}{l}\text { Two political objectives related } \\
\text { to rural energy development }\end{array}$ \\
\hline & & $\begin{array}{l}\text { (3) Near-term } \\
\text { targets }\end{array}$ & Policy discussion & $\begin{array}{l}\text { Planning targets related to rural } \\
\text { energy development }\end{array}$ \\
\hline 3 & \multicolumn{2}{|c|}{ Strategic integration } & $\begin{array}{l}\text { Summaries and } \\
\text { suggestions }\end{array}$ & $\begin{array}{l}\text { Strategic suggestions for } \\
\text { sustainable development of } \\
\text { rural household energy in China }\end{array}$ \\
\hline
\end{tabular}




\subsubsection{Step 1: Identifying Market Status (Operation Systems and Physical Systems)}

The status of Physical systems is first explored by mapping an energy allocation Sankey diagram for China's rural household energy. Second, the behaviors of major market operators in the Operation systems and their impacts on the Physical systems are analyzed by statistical review. Finally, a brief summary is given to describe the dynamic evolution of the rural household energy market.

(1) The Energy Allocation Sankey Diagram

The Sankey diagram is a popular tool to graphically map energy flows, with various types of energy flows presented in different colors and with the width of each flow indicating energy quantities [66,67]. This study integrates statistics from the NSB (national statistics bureau) [68], the Ministry of Agriculture (MOA) [69] and National Bureau of Rural Division (NBRD) [70], and survey data by the BECTU (Building Energy Research Center of Tsinghua University) [9] to decide the balance of rural household energy. To achieve energy balance, no energy loss is presented in the energy allocation Sankey diagram, in order to show the full responsibility of each sector for the total energy consumption. The main data used in the mapping are given in Tables 3 and 4.

Table 3. Main energy types considered in the mapping.

\begin{tabular}{|c|c|c|c|c|}
\hline & Energy Type & Physical Quantity & $\begin{array}{l}\text { Transformation } \\
\text { Factor }\end{array}$ & $\begin{array}{l}\text { Standard Quantity } \\
\text { (Mtce) }\end{array}$ \\
\hline \multirow{3}{*}{ Coal } & Coal counted by the NSB & 1 & 1 & 58.6 \\
\hline & Coal counted by the BECTU & $196.76 \mathrm{Mt}$ & $0.7143 \mathrm{kgce} / \mathrm{kg}$ & 139.8 \\
\hline & Coal not counted by the NSB & / & / & 81.2 \\
\hline \multicolumn{2}{|r|}{ Electricity (by the BECTU) } & 324,296 million $\mathrm{kWh}$ & $0.3 \mathrm{kgce} / \mathrm{kWh}$ & 97.3 \\
\hline \multirow{4}{*}{ Biomass } & Firewood (by the BECTU) & $114.21 \mathrm{Mt}$ & $0.571 \mathrm{kgce} / \mathrm{kg}$ & 65.2 \\
\hline & Crop residues (by the BECTU) & $67.20 \mathrm{Mt}$ & $0.5 \mathrm{kgce} / \mathrm{kg}$ & 33.6 \\
\hline & $\begin{array}{l}\text { Solid biofuels from crop residues } \\
\text { (by the MOA) }\end{array}$ & $5.96 \mathrm{Mt}$ & $0.5 \mathrm{kgce} / \mathrm{kg}$ & 3.0 \\
\hline & Crop residues for traditional use & / & / & 30.6 \\
\hline \multirow{2}{*}{ Gas } & NG (by the NSB) & / & / & 0.2 \\
\hline & Biogas (by the NBRD) & $15,503.95$ million cum & $0.714 \mathrm{kgce} / \mathrm{cum}$ & 11.1 \\
\hline \multirow{3}{*}{$\begin{array}{l}\text { Petroleum } \\
\text { products }\end{array}$} & Petroleum products (by the NSB) & I & I & 19.0 \\
\hline & LPG (by the BECTU) & $8.31 \mathrm{Mt}$ & $1.7143 \mathrm{kgce} / \mathrm{kg}$ & 14.2 \\
\hline & Other petroleum products & / & l & 4.7 \\
\hline \multirow{3}{*}{ Solar } & Solar heaters & 77.83 million $\mathrm{m}^{2}$ & 0.12 tce $/ \mathrm{m}^{2}$ & 9.0 \\
\hline & Solar cookers & 2.30 million sets & $0.31 \mathrm{tce} / \mathrm{set}$ & 0.7 \\
\hline & Solar houses & 25.28 million $\mathrm{m}^{2}$ & $0.03 \mathrm{tce} / \mathrm{m}^{2}$ & 0.8 \\
\hline
\end{tabular}

Because of the complexity of the data sources, we explain all the data in Table 3 as follows:

1. Mtce means million tonnes of coal equivalent. Tce is a popular energy unit in China. 1 tce equals 0.7 toe (tonne oil equivalnent).

2. Standard quantities of coal counted by the NSB, NG, petroleum products, and the transformation factors of coal counted by the BECTU, electricity, firewood, crop residues, solid biofuels from crop residues, LPG, petroleum products and biogas refer to China Energy Statistical Yearbook 2015 by Department of Energy Statistics, National Statistics Bureau.

3. Standard quantities of coal counted by the BECTU, electricity, firewood, crop residues and LPG are taken from 2016 Annual Research Report on Building Energy Saving of China by Building Energy Research Center of Tsinghua University.

4. Physical quantity of solid biofuels from crop residues is taken from China Agricultural Statistics 2014 by the Ministry of Agriculture.

5. Physical quantities of biogas, solar heaters, solar cookers and solar houses are taken from China Rural Statistical Yearbook 2015 by National Bureau of Rural Division. 
6. Transformation factor of solar heaters refers to the paper: Ma LW, Liu P, Fu F, et al. Integrated energy strategy for the sustainable development of China. Energy 2011, 36(2), 1143-1154.

7. Transformation factors of solar cookers and solar houses refer to the paper: Zou XX, Wan YF, $\mathrm{Li}$ YE et al. The effect of energy-saving and emission reduction of solar energy resource utilization in rural areas of china. Renewable Energy Resources 2010, 28, $93-98$ [In Chinese].

8. The italic items or figures are calculated results by authors instead of direct statistics in references.

Table 4. Main sectors of energy consumption considered in the mapping.

\begin{tabular}{|c|c|c|}
\hline Item & Catagory & Standard Quantity (Mtce) \\
\hline \multirow{2}{*}{ Heating for the north } & Coal & 78.8 \\
\hline & Biomass & 25.5 \\
\hline \multirow{2}{*}{ Heating for the south } & Coal & 11.0 \\
\hline & Biomass & 17.5 \\
\hline \multirow{3}{*}{ Cooking for the north } & Coal & 35.9 \\
\hline & Biomass & 29.2 \\
\hline & LPG & 3.8 \\
\hline \multirow{3}{*}{ Cooking for the south } & Coal & 13.1 \\
\hline & Biomass & 22.0 \\
\hline & LPG & 8.8 \\
\hline Heating & $\begin{array}{l}\text { Heating for the north + Heating for the } \\
\text { south + Solar houses }\end{array}$ & 133.6 \\
\hline Cooking & $\begin{array}{l}\text { Cooking for the north + Cooking for the } \\
\text { south }+ \text { NG + Biogas + Solar cookers }\end{array}$ & 124.7 \\
\hline Other residential use & $\begin{array}{l}\text { Electricity }+ \text { The rest petroleum products } \\
+ \text { The rest biomass }+ \text { Solar heaters }\end{array}$ & 118.6 \\
\hline
\end{tabular}

Note: Data of heating for the north, heating for the south, cooking for the north, cooking for the south are directly taken from 2016 Annual Research Report on Building Energy Saving of China by Building Energy Research Center of Tsinghua University. While data of heating, cooking and other residential use are calculated results by authors instead of direct statistics in references.

\section{(2) The Behaviors of Major Market Operators}

The market operators are classified into three groups: (1) Rural residents (farmers) are energy consumers, and their changing energy demands are studied by analyzing the influence of rural population, rural income, and rural lifestyles. (2) Energy suppliers involve centralized energy suppliers and end-use service providers. Centralized energy includes coal, petroleum products, natural gas (NG), centralized power, and centralized heating. End-use services mainly consist of (a) passive systems designed for energy conservation, such as building insulation, heat preservation and ventilation, (b) end-use energy devices, such as heating devices, cooking devices, and electric appliances, and (c) decentralized energy systems, such as distributed energy use of biomass, hydro, wind, solar, and geothermal, with energy resources produced in rural areas. The application status and development trends of various technologies about centralized energy and end-use services are respectively reviewed.

\subsubsection{Step 2: Defining Policy Targets (Sustainable Development Goals and Decision-Making Systems)}

This step aims to recognize sustainable development goals, political will and strategic plans, so as to pinpoint the long-term goals, mid-term objectives, and near-term targets.

First, the origins of sustainable development, its introduction in China, and the main goals of energy for sustainable development in China are reviewed. With some discussion of the rural 
household energy situation in China, the sustainable development goals of rural household energy are concluded as long-term policy targets.

Second, to understand political will and mid-term objectives, we discuss the requirements of China's "Two Centenary Goals" for the development of rural household energy. Then, we summarize political will related to rural household energy by reviewing the 18th and 19th Reports of the National Congress of the Communist Party of China (CPC).

Finally, to understand near-term targets, we review the main planning targets of rural and energy development. The information sources include a series of annual Central Documents No. 1 over the past few years, the 13th Five-Year-Plan (FYP) of Energy Development, and the 13th FYP of Renewable Energy Development.

\subsubsection{Step 3: Proposing Strategic Suggestions (Integrated Strategy)}

Based on the aforementioned analysis, this step proposes top-down strategic suggestions regarding the development of rural household energy according to the I-SDOP concept, from the Sustainable development goals, the Decision-making systems, to the Operation systems and the Physical systems.

\section{Results and Discussion}

\subsection{Market Status}

\subsubsection{The Energy Structure of Rural Households}

The Sankey diagram in Figure 2 shows the structure of rural household energy in China, with the following conclusions:

(1) From the perspective of energy sources, coal (37.1\%), biomass (26.2\%), and electricity (25.8\%) are the main sources of rural household energy. The total amount of rural coal consumption (around $200 \mathrm{Mt}$ ) is within the accepted level when compared with other studies. There is a consensus about the underestimation of actual coal consumption in rural China, especially in northern China $[9,28,59,71]$.

(2) From the perspective of energy distribution, coal is mainly used for heating (64.2\%), while biomass ( $97.0 \%$ traditional) is more used for cooking (51.8\%). Electricity is used for other residential needs, and electric appliances consume most of the rural electricity [9]. Other commercial energy, such as liquefied petroleum gas (LPG), NG, and biogas, are mainly used for cooking. Solar energy is used for heating or cooking in the form of solar heaters, solar cookers, and solar houses.

(3) From the perspective of energy end-use, heating (35.4\%) and cooking (33.1\%) are the two main end-uses of rural household energy consumption, together accounting for $68.5 \%$. This finding is lower than the $86 \%$ ( $43.66 \%$ for cooking and $42.27 \%$ for heating) estimated by Zhou et al. [72] in 2005, and the difference might be explained by rapid electricity demand increase. In more detail, heating for the north, heating for the south, cooking for the north, and cooking for the south respectively represent $27.7 \%, 7.6 \%, 18.3 \%$, and $11.7 \%$ of total energy consumption.

In summary, rural household energy supply in China mainly comes from coal, biomass, and electricity. Cleaner fossil energy (such as NG) and renewable energy (such as solar) are relatively minor. The energy consumption of rural households is mainly in heating and cooking, which are still overly dependent on coal and biomass, far behind the level of urban households ( $88 \%$ choose clean fuels such as NG, electricity, and LPG for cooking [26]). 


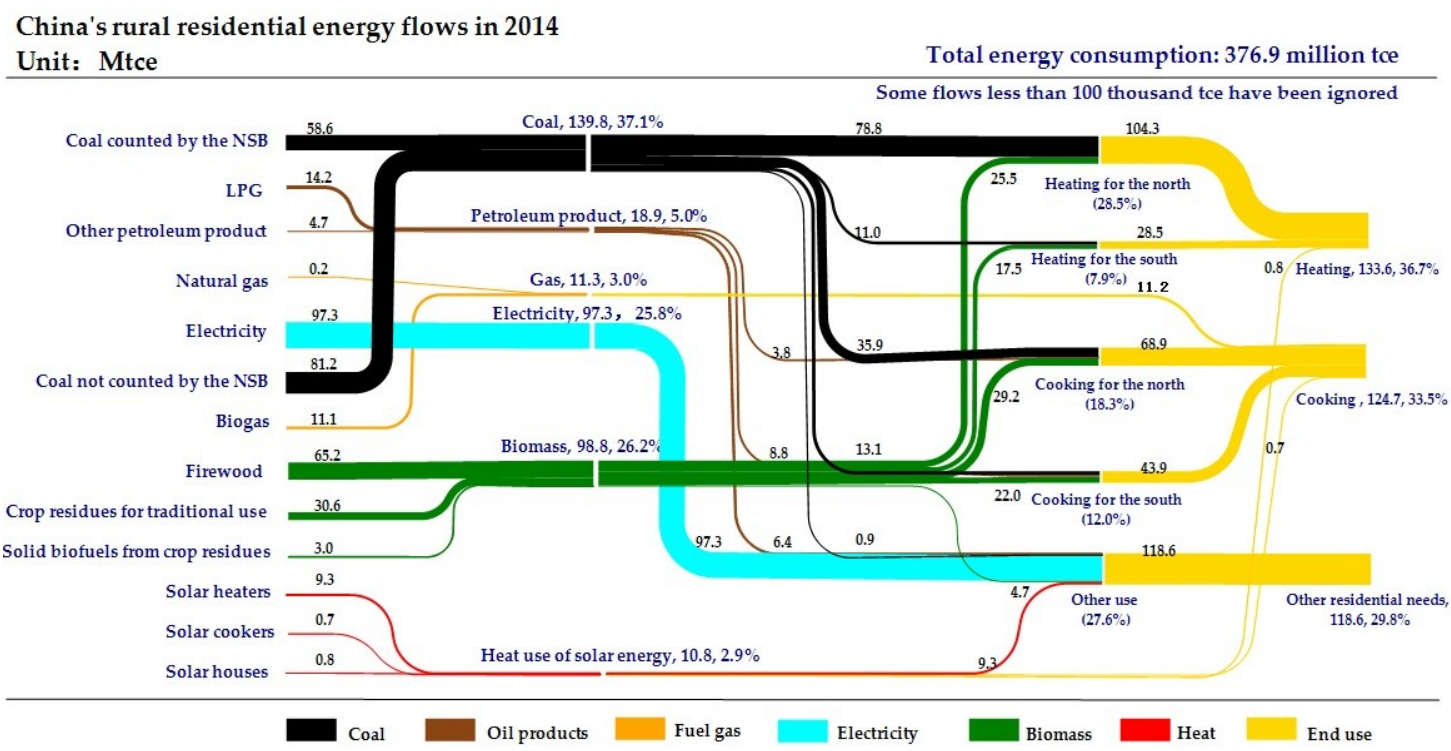

Figure 2. Energy allocation Sankey diagram of China's rural households in 2014.

\subsubsection{Energy Demand of Rural Households}

In recent decades, China's rural economy has undergone rapid development, accompanied by substantial and profound changes in rural lifestyles and a gradual transition in residential energy use patterns with the urbanization process [9,73]. Accordingly, energy demand in rural China has been greatly influenced by changes in rural population, income, and lifestyles.

\section{(1) Rural Population}

From 2000 to 2015, China's rural population has decreased while urban population increased, as shown in Figure 3 [6]. The urbanization rate of China is likely to reach $60 \%$ in 2020 [16] and 77\% in 2050 [74]. Therefore, the reduction of rural population will play a major role in decreasing the rural energy consumption, which is consistent with another study [24].

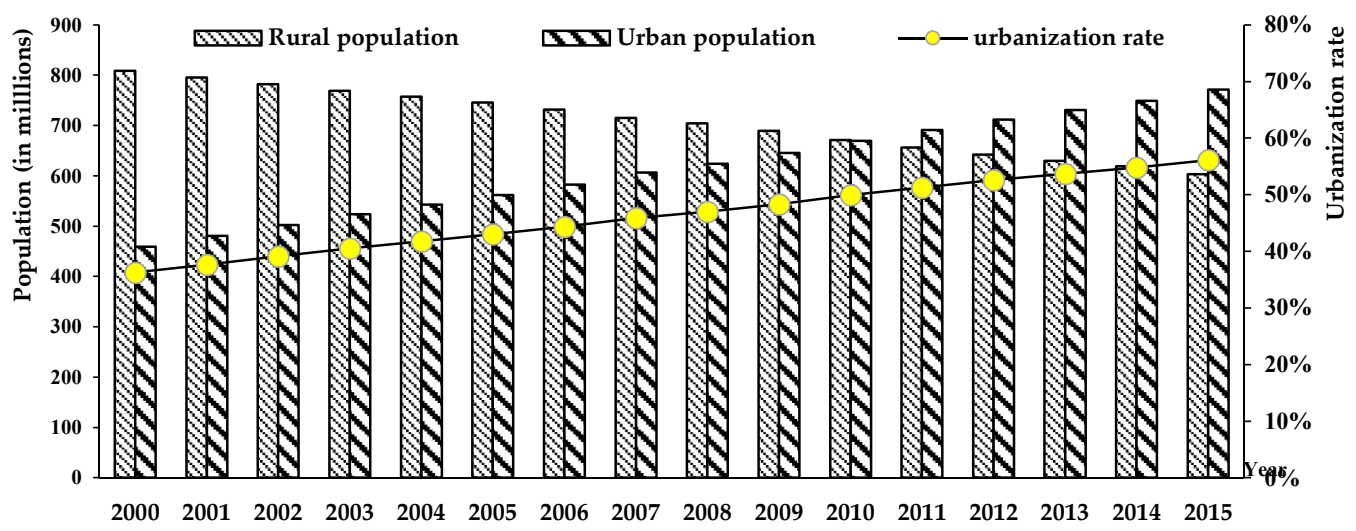

Figure 3. Population and urbanization rate of China from 2000-2015.

\section{(2) Rural income}

Figure 4 shows a slight growth in the per capita agricultural energy consumption and a rapid growth in the per capita residential energy consumption in rural areas. A similar conclusion with previous studies $[7,22-24,30]$ can be made, that income increase is a critical factor in the growth of rural household energy consumption, which may offset the population effect of decreasing rural energy consumption. However, rural income is still much lower than urban income, which could greatly 
limit the realization of equitable energy services in rural and urban areas. Other researchers [22] also suggested that the higher rural income is, the more that versatility, convenience, and cleanliness are considered by individuals. Therefore, augmenting income is a key point to improve rural energy services and to optimize the energy structure $[13,18]$.

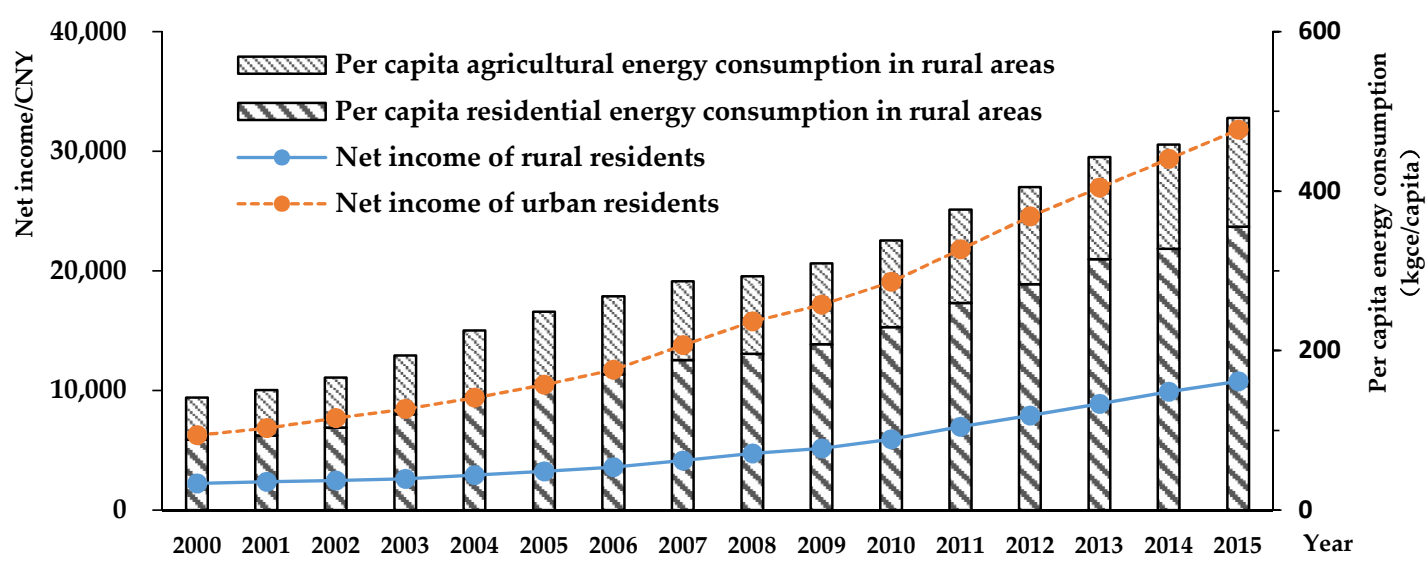

Figure 4. Income and per capita energy consumption in China from 2000-2015 (lines refer to the left Y-axis and columns refer to the right Y-axis).

\section{(3) Lifestyles}

Relatively sparse and distributed rural populations make decentralized single-household residences the dominant type of residences in rural China, with the following characteristics: (1) dispersed locations; (2) small in scale; (3) limited building heating load (for space heating and domestic hot water); and (4) available space around the houses [75]. In general, these typical characteristics are advantages for a distributed energy supply. On the other hand, with the rapid process of urbanization, rural land circulation and centralized residence for rural residents are becoming more and more common in some regions, such as in Chongqing City [76]. The centralized residence trend may further propagate, further increasing per capita residential energy consumption and enhancing requirements for clean and convenient energy services in rural areas. In the future, several forms of rural residences, such as decentralized single houses, small communities, and contiguous centralized residences are likely to coexist, which will require higher diversification and flexibility for rural energy utilization.

\subsubsection{Centralized Energy Supply for Rural Households}

(1) Coal

Although coal consumption by rural households may not increase significantly or even gradually decline with coal substitution in some rural areas like rural Beijing [77], it is hard for it to be completely replaced because of the advantages of low cost [9] and secured supply (66\% of China's total primary energy consumption comes from coal in 2015 [78]). Therefore, clean and quality coal utilization will still play a major role in rural household energy use, especially in coal producing areas.

\section{(2) Petroleum Products and Natural Gas (NG)}

Because of easy transport, as well as better cleanliness and convenience than coal, petroleum products (especially LPG) and NG have seen increased deployment in the rural areas of China, with consumption of petroleum products from 9.4 Mt in 2010 [79] to 18.6 Mt in 2015 [78], and consumption of NG from 68 million cum in 2010 [79] to 143 million cum in 2015 [78]. Foreseeably, with the expansion of NG and its substitution for LPG in urban areas, LPG will become more available and more popular in rural areas. However, higher supply requirements for affordability and large investments for pipe networks make NG utilization still far from universal in rural areas. 


\section{(3) Centralized Power}

Although full coverage of electricity supply all across China had been achieved by the end of 2015 [80], the rural power grid is encountering new challenges, with rapid growth of the rural electricity load. Problems like service interruptions, power surges, and equipment overloads happen frequently [28]. A new round of rural power grid reconstruction and upgrade projects from 2016 to 2020 [81] is in progress, after which, a more sufficient, stable and universal rural power supply can be expected.

\section{(4) Centralized Heating}

Besides large-scale thermal power plants or heating boilers, centralized heating also requires costly heating pipelines and centralized heat consumers. Therefore, most rural areas are not currently suitable for centralized heating supply. With the popularity of centralized residences in some rural areas, centralized heating might become a good choice for centralized residences in the future.

\subsubsection{End-Use Services in Rural Household Energy}

\section{(1) Passive Systems}

Passive energy-conservation design (e.g., better wall insulation and fenestration, passive solar houses [82]) is particularly significant for improving the thermal performance and comfort of rural residences. However, energy conservation retrofits for rural residences have just started and are making slow progress, mostly in economically developed zones or key development zones. Only 1.176 million rural households have implemented energy-conservation retrofits as of 2015 [83]. Passive energy-conservation design and retrofits need to further expand in rural areas, with increasing policy support to overcome problems of organization and financing [84].

(2) Heating devices

At present, firewood and coal are still the primary energy sources for active rural heating, which makes stoves essential for pollutant control. Retrofit projects of efficient and clean burning stoves to control coal burning pollution in rural areas have been carried out in regions like Hebei province [85]. More efficient and clean stoves need further promotion for universal energy efficiency increase and effective pollutant control in rural areas.

\section{(3) Cooking Devices}

Coal and biomass are still the predominant fuel sources for cooking in rural China. Thus, upgrading and replacing existing stoves for coal, firewood, and crop straw is a more practical technical choice in the transitional period for most rural areas. Besides, rural cooking fuels are transitioning to clean sources such as electricity and LPG due to increasing accessibility and affordability [13]. In the long run, electricity and fuel gas (NG, LPG, and biogas, etc.) might become the main energy source for cooking, especially for regions with good economic conditions like the Yangtze River Delta zone, and the south-west region where hydropower is abundant. On the whole, technology choices for rural cooking have shown a trend toward diversification and cleanliness.

\section{(4) Electric Appliances}

Electric appliances have become more and more efficient and affordable in rural areas. Energy consumption for rural lighting decreased by 50\% from 2004 to 2014 due to technical progress [9]. Household appliance usage increases with rural income improvement and changes in the concept of consumption. Furthermore, the policy support for rural home appliances [86] has made color televisions, washing machines, refrigerators, etc. become increasingly affordable for rural residents since 2008. Therefore, it is expected that the use of electric appliances will progressively increase in rural areas for a long time. 


\section{(5) Distributed Energy Systems}

Most distributed renewable systems, such as distributed power supply systems, distributed co-generation systems for heat and power, and hot water and heating systems are technically mature, but still face challenges from high costs, inherent instability, or inadequate convenience. A new pathway to promote the synergic utilization of various distributed energy with advanced information technologies is gaining popularity. Future trends in rural areas mainly include: (1) the utilization of solar energy incorporating electricity, clean coal, NG, solid densified biofuels, and so on for cooking, heating and hot water; (2) the development of micro-grids that integrate a set of micro sources such as micro-turbines, fuel cells, PV (photovoltaic) arrays, wind turbines, and storage systems to lower investment costs, improve power quality, and enhance control flexibility [87,88]; and (3) the combination of information technologies such as cloud computing, the internet of things, and big data with rural energy development for more efficient management [89].

\subsubsection{Dynamic Evolution of the Rural Household Energy Market}

The dynamics of rural household energy system result from interactions and gaming by energy consumers, centralized energy suppliers, and end-use service suppliers. Overall, three evolutionary stages of the rural household energy market can be summarized according to results of the above analysis and literature review $[12,54,55]$, as shown in Figure 5.

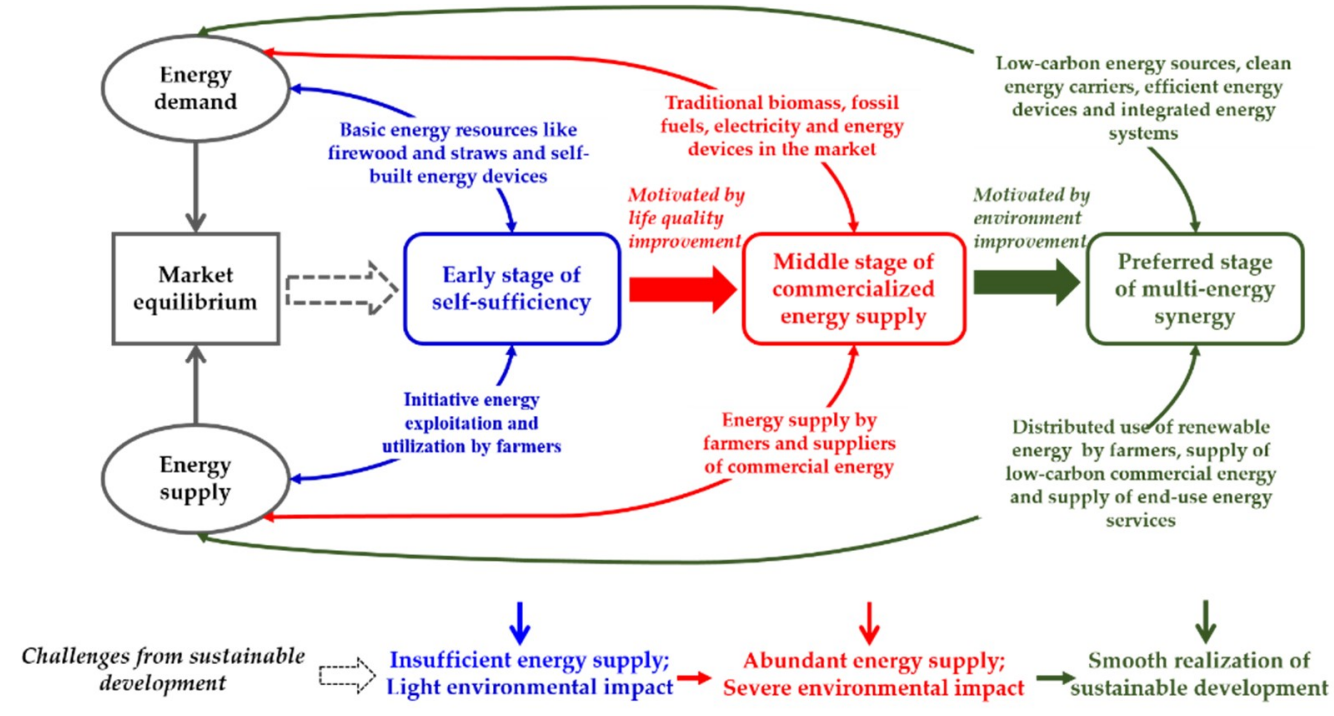

Figure 5. Dynamic evolution of rural household energy development in China.

(1) Early stage of self-sufficiency: farmers dominated the market as both energy suppliers and demanders, resulting in a biomass-dominant rural energy structure and persistent rural poverty. Energy supply is insufficient and energy use is inconvenient at this stage, but a minor environmental influence enabled rural areas to maintain a healthy environment.

(2) Middle stage of centralized energy supply: centralized energy suppliers become prominent in the market. A heavy use of both coal and biomass can be observed at this stage. However, accompanying problems are widespread, such as air pollution and greenhouse gas emission. End-use services is a limited role for lack of professional services. Currently, the development of rural household energy in China remains at this stage.

(3) Preferred stage of multi-energy synergy: end-use service suppliers, centralized energy suppliers and farmers together positively influence the rural energy market. Synergy of various energy types and energy technologies became universal at this stage. Different forms of synergistic systems, combined with advanced information technologies, will enable the rural household 
energy system to be more modern, smarter, cleaner, and lower in carbon, so as to achieve equitable energy services in both rural and urban areas. This is a sustainable development path worth exploring.

\subsection{Policy Targets}

\subsubsection{Sustainable Development Goals}

The concept of sustainable development has been accepted worldwide since 1987 [90]. In 1992, Agenda 21 [91], a non-binding, voluntarily implemented action plan of the United Nations with regard to sustainable development, was officially approved. In 1994, the Chinese government released China's Agenda 21 [92] to officially agree on sustainable development. A representative view [93] derived from China's Agenda 21 in literature is that China's energy strategies are required, at the earliest opportunity, to fulfill four key objectives: (1) to meet the power needed for economic growth; (2) to ensure energy supply security; (3) to guarantee the protection of public health and the environment; and (4) to achieve an equitable distribution of energy services throughout the nation. These principles can mostly adapt to the sustainable development of rural areas.

However, with undeveloped economies and lagging infrastructures, rural China is still widely hindered by energy poverty. Priority must be given to addressing energy poverty for rural sustainable development. Thus, we conclude that the constraining principles of rural energy sustainable development are: (1) energy security, defined as the ability of rural households to rely on a constant energy supply; (2) energy equity, meaning the ability of rural households to acquire adequate energy service, comparable to that in urban areas; and (3) ensuring human safety and environmental protection, hardly any health impact and environmental pollution from rural energy utilization.

\subsubsection{Political Will}

China's political will is both shaped by external and internal must-do missions. For external requirements, China submitted China's Intended Nationally Determined Contributions (INDC) [94] in 2015, promising to achieve the peaking of $\mathrm{CO}_{2}$ emissions around 2030. Therefore, there should be no drastic increase in carbon emissions from rural household energy utilization. For internal aspirations, China has defined the "Two Centenary Goals" since the 18th National Congress of the CPC in 2012 [95]. Two political goals on rural energy can be extracted specifically from the "Two Centenary Goals". One is about a revolution in energy production and consumption $[95,96]$ and the other is rural development [94-96]. It is stressed that "Issues relating to agriculture, rural areas, and rural people are fundamental to China as they directly concern our country's stability and our people's wellbeing" [96]. Nevertheless, the two political targets are relatively separated from one another, resulting in insufficient attention towards rural energy development in policy making.

\subsubsection{Strategic Plans}

Rural development and energy development have always garnered high attention in official plans. Despite that, plans for rural development and energy development have been largely separately formulated.

Resolving the "Three-agro Issues" (agriculture, rural areas and farmers) has always been considered as the first priority among the priorities of the CPC. The Chinese government released a series of Central Documents No. 1 about the "Three-agro Issues" at the beginning of each year from 1982 to 1986, then since 2004 [97]. The No. 1 documents from 2004 to 2011 pay more attention to rural income improvement and rural infrastructure construction, while the themes from 2012 to 2017 remains the modernization of agriculture. Rural power grid reconstruction and upgrading, small hydropower, small wind power, small PV power, and rural biogas have also been mentioned many times, but no systematic plan for rural energy development can be found in the annual plans for rural development. 
Under the direction of the political will on energy revolution, the Chinese government has also made general deployment in the FYPs and other plans to carry out the revolution in energy production and consumption. In the 12th FYP for Energy Development [98], an implementation of energy livelihood projects is formulated, including speeding up the construction of rural power grids, vigorously developing rural renewable energy, and improving the basic service systems of rural energy. The 13th FYP for Energy Development [99] attaches importance to achieving the development of energy sharing, which involves enhancing the residential energy infrastructure, accurately implementing energy poverty alleviation projects, improving the level of universal energy services, and vigorously developing rural clean energy. The planning focuses have shifted from energy infrastructure construction to energy service improvement, with consistent persistency for rural clean energy development. However, according to the 13th FYP for Building Energy Conservation and Green Building Development [82], the focus of this plan is still mainly building energy conservation in town areas, with less mention of energy conservation for rural residences.

In summary, in current political will and planning targets, rural energy issues have not been fully considered, as rural development and energy development are disconnected in the plans. This leads to an absence of clear policy targets for rural energy development. Additionally, policy implementation is mainly from top-down and through pilot projects [39], indicating a lack of sufficient support for possible initiatives in the market.

\subsection{Strategic Integration}

According to the above analysis, the development of rural household energy in China must follow the sustainable development goals to build a clean, low-carbon, and smart energy system, which can provide widespread energy services for rural households that are convenient, economical, and high-quality.

To realize these high-level goals, the policy targets of rural and energy planning must be better coordinated. In policy-making and planning related to the "Three-agro Issues", systematic plans for the development of rural energy, especially rural household energy, are urgently required. On the other hand, in energy planning, there is an emergent need to give more prominence to rural household energy. More importantly, the two must be closely linked. To this end, innovative mechanisms are desperately needed to break the currently fragmented administration.

Following such policy targets, a new system of technology innovation in market operations is required to facilitate a smooth transition to the stage of multi-energy synergy. The key is to combine various forms of energy technologies with advanced system integration and information technologies, enabling household energy utilization in rural areas to be more modern, smarter, cleaner, and lower in carbon. An equal participation of the three main market operators, including farmers, centralized energy suppliers, and end-use service suppliers, is urgently required to build a new system of technology innovation to realize a strong synergy among them. Corresponding policies must be enacted to enable their equal participation based on market mechanisms.

To realize multi-energy synergy in rural areas, key technical routes include: (1) giving priority to energy conservation. First, passive energy-conservation designs or retrofits of rural residences must be widely promoted. Second, the efficiency of active energy use from the aspect of energy supply, conversion, and end-use must be further improved. (2) Continuously optimizing the three main incumbent energy sources. Coal can still play a role for rural cooking and heating if better quality and cleanliness is ensured. Electricity will become increasingly significant as rural power grid reconstruction and upgrading continue to improve power supply capacity and reliability. Biomass should be used more in modern approaches to reduce pollution and increase efficiency. (3) Developing a certain amount of expedient alternative energy, such as LPG and NG, where conditions permit. (4) Actively developing desirable energy for sustainable development in the future. The development of solar thermal utilization, distributed generation, micro-grids, etc. in rural areas must be encouraged. The problems of rural household energy will not be readily solved 
by any single energy or technology, but will benefit gradually from the synergy of multiple energies and technologies.

Moreover, as it is difficult to solve the problem of rural household energy in various regions with one standardized approach, engineering and policy design must adequately consider local conditions. This will require greater flexibility in project construction and policy making for rural household energy. Thus, it is vital to encourage spontaneous innovation in difference regions, and to avoid one-size-fits-all thinking of technology promotion under the traditional thinking of large-industry management and vertical management systems. The careful planning and management of the life cycle of investment projects according to the regional characteristics is also an important measure to prevent the waste of construction energy consumption and avoid the corresponding carbon emissions [100].

\section{Conclusions and Suggestions}

This manuscript presents a complete picture of the status quo and future trends in the development of rural household energy in China, according to a literature review and a systems analysis based on the I-SDOP concept. The main focused points of the study are the actual energy mix, prioritized technology choices, and the innovation required in market operations and governmental policies. The main conclusions are as follows:

(1) Currently, rural household energy is dominated by coal, biomass, and electricity from the centralized power grid, and mostly consumed for cooking, heating, and household appliances. Meanwhile, an obvious transformation from non-commercial energy to commercial energy can be found during the rapid urbanization process in China.

(2) Confronted with challenges of low energy efficiency, environmental pollution and $\mathrm{CO}_{2}$ emissions, a pathway of multi-energy synergy should be adopted for the sustainable development of rural household energy. Synthetic use of both passive and active energy systems, by utilizing various energies such as coal, biomass and renewable energy, can better fit rural household energy development in China.

(3) The key is to promote bottom-up regional innovation of rural household energy development according to local conditions, especially innovation in financing and business models for stakeholders to collaborate and to promote profitability.

(4) Policy-making must make clear targets by coordinating rural development and energy development, so as to support regional innovation of multi-energy synergy as a whole.

Moreover, successful experiences of rural energy development in other countries are also worth learning from. For example, business model innovation of farm-produced biogas in an agricultural network of Sweden is emphasized [101]. A wind park in a town of Germany was designed in a way that would involve investors, local citizens and local council to form a community of interest [102]. Overall, most researchers, especially those in western countries, argue that renewable energy is preferable in rural areas or remote communities. For instance, more than 100 German communities and regions have committed to target $100 \%$ renewable energy supply [103]. However, synergy of both fossil energy (especially coal) and renewable energy is more feasible for the rural areas of China, since China has different resource endowment and development conditions.

In the next step, several issues are suggested for further study on the development of rural household energy in China: (1) the development of an authorized database to eliminate data discrepancies; (2) a study of appropriate market mechanisms and policy instruments for multi-energy synergy; (3) the design and optimization of a system of schemes of multi-energy synergy according to temporal and regional variations.

Author Contributions: Min He, Chinhao Chong, and Linwei Ma coordinated the main theme of this paper and wrote this manuscript. Linwei Ma, Xu Li and Shizhong Song discussed the research results and commented on the manuscript. The final review was done by Linwei Ma, Pei Liu, Zheng Li and Weidou Ni. All the authors read and approved the final manuscript. 
Funding: This research was supported by the Chinese Academy of Engineering (Project No. 2016-ZD-14-2); the National Natural Science Foundation of China (Project No. 71690245); and the State Key Laboratory of Power Systems in Tsinghua University (Project No. SKLD17Z02).

Acknowledgments: The authors gratefully acknowledge the financial support of the BP Company in the context of the Phase III Collaboration between BP and Tsinghua University, and from the Rio Tinto Group in the context of the Tsinghua-Rio Tinto Joint Research Centre for Resources, Energy and Sustainable Development, Laboratory for Low Carbon Energy.

Conflicts of Interest: The authors declare no conflicts of interest.

\section{Abbreviations}

BECTU Building Energy Research Center of Tsinghua University

CESY China Energy Statistical Yearbook

I-SDOP Integrated strategy of Sustainable development objectives,

Decision-making systems, Operation systems, and Physical system

NSB National Statistics Bureau

Tce Tonne coal equivalent

Mt Million tonnes

FYP Five-Year Plan

CPC Communist Party of China

\section{References}

1. MacCarty, N.A.; Bryden, K.M. Costs and impacts of potential energy strategies for rural households in developing communities. Energy 2017, 138, 1157-1174. [CrossRef]

2. Stephen, J.D.; Mabee, W.E.; Pribowo, A.; Pledger, S.; Hart, R.; Tallio, S.; Bull, G.Q. Biomass for residential and commercial heating in a remote Canadian aboriginal community. Renew. Energy 2016, 86, 563-575. [CrossRef]

3. Akinyele, D.O.; Rayudu, R.K. Strategy for developing energy systems for remote communities: Insights to best practices and sustainability. Sustain. Energy Technol. Assess. 2016, 16, 106-127. [CrossRef]

4. Byrnes, L.; Brown, C.; Wagner, L.; Foster, J. Reviewing the viability of renewable energy in community electrification: The case of remote Western Australian communities. Renew. Sustain. Energy Rev. 2016, 59, 470-481. [CrossRef]

5. Afsharzade, N.; Papzan, A.; Ashjaee, M.; Delangizan, S.; van Passel, S.; Azadi, H. Renewable energy development in rural areas of Iran. Renew. Sustain. Energy Rev. 2016, 65, 743-755. [CrossRef]

6. Ni, W.D.; Xia, Z.N.; Chen, Z.L. Energy Science Volume of the Great Dictionary; Shanghai Dictionary Press: Shanghai, China, 2013. (In Chinese)

7. Zhang, L.X.; Wang, C.B.; Bahaj, A.S. Carbon emissions by rural energy in China. Renew. Energy 2014, 66, 641-649. [CrossRef]

8. Liu, W.L.; Wang, C.; Mol, A.P.J. Rural household $\mathrm{CO}_{2}$ emissions in China: Where is the major mitigation potential? Energy Policy 2012, 51, 223-232. [CrossRef]

9. Building Energy Research Center of Tsinghua University. 2016 Annual Research Report on Building Energy Saving of China; China Architecture \& Building Press: Beijing, China, 2016. (In Chinese)

10. National Bureau of Statistics of China. China Statistical Yearbook 2017; China Statistics Press: Beijing, China, 2016.

11. Liang, L.; Wu, W.L.; Lal, R.; Guo, Y.B. Structural change and carbon emission of energy consumption of rural households in Huantai, northern China. Renew. Sustain. Energy Rev. 2013, 28, 767-776. [CrossRef]

12. Zhang, L.; Yang, Z.; Chen, B.; Chen, G. Rural energy in China: Pattern and policy. Renew. Energy 2009, 34, 2813-2823. [CrossRef]

13. Liao, H.; Tang, X.; Wei, Y.M. Solid fuel use in rural China and its health effects. Renew. Sustain. Energy Rev. 2016, 60, 900-908. [CrossRef]

14. Li, Q.; Jiang, J.K.; Wang, S.X.; Rumchev, K.; Mead-Hunter, R.; Morawska, L.; Hao, J. Impacts of household coal and biomass combustion on indoor and ambient air quality in China: Current status and implication. Sci. Total Environ. 2017, 576, 347-361. [CrossRef] [PubMed] 
15. Ye, W.; Zhang, X.; Gao, J.; Cao, G.Y.; Zhou, X.; Su, X. Indoor air pollutants, ventilation rate determinants and potential control strategies in Chinese dwellings: A literature review. Sci. Total Environ. 2017, 586, 696-729. [CrossRef] [PubMed]

16. Chen, J.M.; Li, C.L.; Ristovski, Z.; Milic, A.; Gu, Y.T.; Islan, M.S.; Wang, S.; Hao, J.; Zhang, H.; He, C.; et al. A review of biomass burning: Emissions and impacts on air quality, health and climate in China. Sci. Total Environ. 2017, 579, 1000-1034. [CrossRef] [PubMed]

17. Ma, L.W.; Liu, P.; Fu, F.; Li, Z.; Ni, W.D. Integrated energy strategy for the sustainable development of China. Energy 2011, 36, 1143-1154. [CrossRef]

18. Chong, C.H.; Ni, W.D.; Ma, L.W.; Liu, P.; Li, Z. The Use of Energy in Malaysia: Tracing Energy Flows from Primary Source to End Use. Energies 2015, 8, 2828-2866. [CrossRef]

19. Ma, L.W.; Fu, F.; Li, Z.; Liu, P. Oil development in China: Current status and future trends. Energy Policy 2012, 45, 43-53. [CrossRef]

20. Wu, J.X.; Yang, J.; Ma, L.W.; Li, Z.; Shen, X.S. A system analysis of the development strategy of iron ore in China. Resour. Policy 2016, 48, 32-40. [CrossRef]

21. Cai, J.; Jiang, Z.G. Changing of energy consumption patterns from rural households to urban households in China: An example from Shaanxi Province, China. Renew. Sustain. Energy Rev. 2008, 12, 1667-1680. [CrossRef]

22. Fan, J.; Liang, Y.T.; Tao, A.J.; Sheng, K.R.; Ma, H.L.; Xu, Y.; Wang, C.-S.; Sun, W. Energy policies for sustainable livelihoods and sustainable development of poor areas in China. Energy Policy 2011, 39, 1200-1212. [CrossRef]

23. Yao, C.S.; Chen, C.Y.; Li, M. Analysis of energy consumption of rural households and corresponding carbon emissions in China. Energy Policy 2012, 41, 445-450. [CrossRef]

24. Zhang, M.; Guo, F.Y. Analysis of rural residential commercial energy consumption in China. Energy 2013, 52, 222-239. [CrossRef]

25. Zhang, M.; Song, Y.; Li, P.; Li, H.N. Study on affecting factors of residential energy consumption in urban and rural Jiangsu. Renew. Sustain. Energy Rev. 2016, 53, 330-337. [CrossRef]

26. Hou, B.D.; Tang, X.; Ma, C.B.; Liu, L.; Wei, Y.M.; Liao, H. Cooking fuel choice in rural China: Results from microdata. J. Clean. Prod. 2017, 143, 538-547. [CrossRef]

27. Duan, X.L.; Jiang, Y.; Wang, B.B.; Zhao, X.G.; Shen, G.F.; Gao, S.Z.; Huang, N.; Qian, Y.; Chen, Y.; Wang, L. Household fuel use for cooking and heating in China: Results from the first Chinese Environmental Exposure-Related Human Activity Patterns Survey (CEERHAPS). Appl. Energy 2014, 136, 692-703. [CrossRef]

28. Wang, R.; Jiang, Z.J. Energy consumption in China's rural areas: A study based on the village energy survey. J. Clean. Prod. 2017, 143, 452-461. [CrossRef]

29. Wang, X.H.; Li, K.Q.; Li, H.; Bai, D.; Liu, J.R. Research on China's energy consumption of rural households Household investigation of typical counties in 8 economic zones. Renew. Sustain. Energy Rev. 2017, 68, $28-32$.

30. Fan, J.L.; Zhang, Y.J.; Wang, B. The impact of urbanization on residential energy consumption in China: An aggregated and disaggregated analysis. Renew. Sustain. Energy Rev. 2017, 75, 220-233. [CrossRef]

31. Fan, J.L.; Yu, H.; Wei, Y.M. Residential energy-related carbon emissions in urban and rural China during 1996-2012: From the perspective of five end-use activities. Energy Build. 2015, 96, 201-209. [CrossRef]

32. Li, C.B.; He, L.N.; Cao, Y.J.; Xiao, G.X.; Zhang, W.; Liu, X.H.; Yu, Z.; Tan, Y.; Zhou, J. Carbon emission reduction potential of rural energy in China. Renew. Sustain. Energy Rev. 2014, 29, 254-262. [CrossRef]

33. Tang, X.; Liao, H. Energy poverty and solid fuels use in rural China: Analysis based on national population census. Energy Sustain. Dev. 2014, 23, 122-129. [CrossRef]

34. Zhang, H.F.; Hu, J.; Qi, Y.X.; Li, C.L.; Chen, J.M.; Wang, X.M.; He, J.; Wang, S.; Hao, J.; Zhnag, L.; et al. Emission characterization, environmental impact, and control measure of $\mathrm{PM}_{2.5}$ emitted from agricultural crop residue burning in China. J. Clean. Prod. 2017, 149, 629-635. [CrossRef]

35. Liu, H.; Jiang, G.M.; Zhuang, H.Y.; Wang, K.J. Distribution, utilization structure and potential of biomass resources in rural China: With special references of crop residues. Renew. Sustain. Energy Rev. 2008, 12, 1402-1418. [CrossRef]

36. Jiang, D.; Zhuang, D.F.; Fu, J.Y.; Huang, Y.H.; Wen, K. Bioenergy potential from crop residues in China: Availability and distribution. Renew. Sustain. Energy Rev. 2012, 16, 1377-1382. [CrossRef]

37. Qiu, H.G.; Sun, L.X.; Xu, X.L.; Cai, Y.Q.; Bai, J.F. Potentials of crop residues for commercial energy production in China: A geographic and economic analysis. Biomass Bioenergy 2014, 64, 110-123. [CrossRef] 
38. Tan, Z.F.; Chen, K.T.; Liu, P.K. Possibilities and challenges of China's forestry biomass resource utilization. Renew. Sustain. Energy Rev. 2015, 41, 368-378. [CrossRef]

39. Byrne, J.; Zhou, A.M.; Shen, B.; Hughes, K. Evaluating the potential of small-scale renewable energy options to meet rural livelihoods needs: A GIS- and lifecycle cost-based assessment of Western China's options. Energy Policy 2007, 35, 4391-4401. [CrossRef]

40. He, G.; Kammen, D.M. Where, when and how much wind is available? A provincial-scale wind resource assessment for China. Energy Policy 2014, 74, 116-122. [CrossRef]

41. He, G.; Kammen, D.M. Where, when and how much solar is available? A provincial-scale solar resource assessment for China. Renew. Energy 2016, 85, 74-82. [CrossRef]

42. Xu, C.X.; Zhou, Y.L.; Jing, J.L.; Chen, X.C. Potential evaluation of small hydropower development and utilization. Water Resour. Power 2011, 29, 145-148. (In Chinese)

43. Zhuang, Z.; Li, Y.G.; Chen, B.; Guo, J.Y. Chinese kang as a domestic heating system in rural northern China-A review. Energy Build. 2009, 41, 111-119. [CrossRef]

44. Zhai, Z.Q.; Yates, A.P.; Duanmu, L.; Wang, Z.S. An evaluation and model of the Chinese Kang system to improve indoor thermal comfort in northeast rural China-Part-1: Model development. Renew. Energy 2015, 84, 3-11. [CrossRef]

45. Zhai, Z.Q.; Yates, A.P.; Duanmu, L.; Wang, Z.S. An evaluation and model of the Chinese Kang system to improve indoor thermal comfort in northeast rural China-Part-2: Result analysis. Renew. Energy 2015, 84, 12-21. [CrossRef]

46. Gosens, J.; Lu, Y.L.; He, G.Z.; Bluemling, B.; Beckers, T.A.M. Sustainability effects of household-scale biogas in rural China. Energy Policy 2013, 54, 273-287. [CrossRef]

47. Deng, Y.F.; Xu, J.P.; Liu, Y.; Mancl, K. Biogas as a sustainable energy source in China: Regional development strategy application and decision making. Renew. Sustain. Energy Rev. 2014, 35, 294-303. [CrossRef]

48. Wang, X.J.; Lu, X.G.; Yang, G.H.; Feng, Y.Z.; Ren, G.X.; Han, X.H. Development process and probable future transformations of rural biogas in China. Renew. Sustain. Energy Rev. 2016, 55, 703-712. [CrossRef]

49. Song, S.Z.; Liu, P.; Xu, J.; Chong, C.H.; Huang, X.Z.; Ma, L.W.; Li, Z.; Ni, W. Life cycle assessment and economic evaluation of pellet fuel from corn straw in China: A case study in Jilin Province. Energy 2017, 130, 373-381. [CrossRef]

50. Song, S.Z.; Liu, P.; Xu, J.; Ma, L.W.; Chong, C.H.; He, M.; Huang, X.; Li, Z.; Ni, W. An economic and policy analysis of a district heating system using corn straw densified fuel: A case study in Nong'an County in Jilin Province, China. Energies 2016, 10, 8. [CrossRef]

51. Zhu, J.Y.; Chen, B. Simplified analysis methods for thermal responsive performance of passive solar house in cold area of China. Energy Build. 2013, 67, 445-452. [CrossRef]

52. Shan, M.; Yu, T.; Yang, X. Assessment of an integrated active solar and air-source heat pump water heating system operated within a passive house in a cold climate zone. Renew. Energy 2016, 87, 1059-1066. [CrossRef]

53. Tian, Y.S. Current status and outlook of the development of China's rural energy in 2015. China Energy 2016, 38, 25-29. (In Chinese)

54. Zhu, S.H. China's rural energy policies: Review and outlook. Agric. Eng. Technol. (Renew. Energy Ind.) 2009, 9, 3-8. (In Chinese)

55. Liu, X.; Hu, Y.; Xiao, Y. Risk management for rural energy industry of Sichuan Province in China. Renew. Sustain. Energy Rev. 2017, 69, 1029-1044. [CrossRef]

56. Zhang, P.D.; Yang, Y.L.; Shi, J.; Zheng, Y.H.; Wang, L.S.; Li, X.R. Opportunities and challenges for renewable energy policy in China. Renew. Sustain. Energy Rev. 2009, 13, 439-449.

57. He, B.J.; Yang, L.; Ye, M.; Mou, B.; Zhou, Y.N. Overview of rural building energy efficiency in China. Energy Policy 2014, 69, 385-396. [CrossRef]

58. Chai, F.H.; Xue, Z.G.; Zhi, G.R.; Du, J.H.; Luo, Y.F.; Ren, Y.B. Complex Control Measures of Rural Coal Combustion Pollution. Environ. Prot. 2016, 6, 15-19. (In Chinese)

59. Huo, M.L.; Zhao, J.; Xu, Z.; Shan, B.G.; Jia, D.X. China Scattered Coal Consumption Map and Influence Factors. Electr. Power 2018, 51, 139-146. (In Chinese)

60. Zhang, M.; Su, B. Assessing China's rural household energy sustainable development using improved grouped principal component method. Energy 2016, 113, 509-514. [CrossRef]

61. Ma, L.W.; Allwood, J.M.; Cullen, J.M.; Li, Z. The use of energy in China: Tracing the flow of energy from primary source to demand drivers. Energy 2012, 40, 174-188. [CrossRef] 
62. Ma, L.W.; Zhang, T.K.; Zhang, X.; Chong, C.H.; Liu, P.; Li, Z.; Ni, W.D. A Review of China's Energy Systems and the Dynamics in 2000-2015. In Proceedings of the 9th International Conference on Sustainable Energy and Environment Protection (SEEP) 2016, Kayseri, Turkey, 22-24 September 2016.

63. Chong, C.H.; Ma, L.W.; Li, Z.; Ni, W.D.; Song, S.Z. Logarithmic mean Divisia index (LMDI) decomposition of coal consumption in China based on the energy allocation diagram of coal flows. Energy 2015, 85, 366-378. [CrossRef]

64. Geng, J. Feasibility of Natural Gas Trade between China and Canada based on System Modeling and Analysis. Master's Thesis, Tsinghua University, Beijing, China, 2015.

65. Chong, C.H.; Liu, P.; Ma, L.W.; Li, Z.; Ni, W.D.; Li, X.; Song, S.Z. LMDI decomposition of energy consumption in Guangdong Province, China, based on an energy allocation diagram. Energy 2017, 133, 525-544. [CrossRef]

66. Schmidt, M. The Sankey diagram in energy and material flow management-Part II: Methodology and current applications. J. Ind. Ecol. 2008, 12, 173-185. [CrossRef]

67. Soundararajan, K.; Ho, H.K.; Su, B. Sankey diagram framework for energy and exergy flows. Appl. Energy 2014, 136, 1035-1042. [CrossRef]

68. Department of Energy Statistics, National Bureau of Statistics, People's Republic of China. China Energy Statistical Yearbook 2015; China Statistics Press: Beijing, China, 2015.

69. Ministry of Agriculture. China Agricultural Statistics 2014; China Agricultural Press: Beijing, China, 2015. (In Chinese)

70. National Bureau of Rural Division. China Rural Statistical Yearbook 2015; China Statistics Press: Beijing, China, 2015. (In Chinese)

71. Zhi, G.R.; Zhang, Y.Y.; Sun, J.Z.; Cheng, M.; Dang, H.; Liu, S.; Yang, J.; Zhang, Y.; Xue, Z.; Li, S.; et al. Village energy survey reveals missing rural raw coal in northern China: Significance in science and policy. Environ. Pollut. 2017, 223, 705-712. [CrossRef] [PubMed]

72. Zhou, Z.R.; Wu, W.L.; Wang, X.H.; Chen, Q.; Wang, Q. Analysis of changes in the structure of rural household energy consumption in northern China: A case study. Renew. Sustain. Energy Rev. 2009, 13, 187-193. [CrossRef]

73. Sun, C.W.; Ouyang, X.L.; Cai, H.B.; Luo, Z.; Li, C. Household pathway selection of energy consumption during urbanization process in China. Energy Convers. Manag. 2014, 84, 295-304. [CrossRef]

74. United Nations. World Urbanization Prospects: The 2014 Revision. Available online: http://www.un. org/en/development/desa/publications / 2014-revision-world-urbanization-prospects.html (accessed on 20 October 2017).

75. Liu, Z.J.; Li, Z.; Li, A.S.; Feng, A.; Jia, C. Research on Solar Heating Technology for Rural Single Family Homes in Severe Cold and Cold Zones of China. In Proceedings of the Tenth International Conference on Green Building and Energy Saving and New Technology and Products Expo, Beijing, China, 28-30 March 2014. (In Chinese)

76. Yang, J.; Zhang, W.; Zhang, Z.Y. Impacts of urbanization on renewable energy consumption in China. J. Clean. Prod. 2016, 114, 443-451. [CrossRef]

77. Central Government of PRC. Beijing: The City's 126,000 Households Have Completed “Coal to Gas". Available online: http://www.gov.cn/xinwen/2018-01/08/content_5254290.htm (accessed on 12 March 2018).

78. Department of Energy Statistics, National Bureau of Statistics, People's Republic of China. China Energy Statistical Yearbook 2016; China Statistics Press: Beijing, China, 2016.

79. Department of Energy Statistics, National Bureau of Statistics, People's Republic of China. China Energy Statistical Yearbook 2011; China Statistics Press: Beijing, China, 2011.

80. Department of Energy Statistics, National Bureau of Statistics, People's Republic of China. The Task of Comprehensively Solving the Problem of Electricity Consumption Without Electricity Population Has Been Satisfactorily Completed in the Country. Available online: http:/ / www.nea.gov.cn/2015-12/24/C_ 134948340.htm (accessed on 15 October 2017).

81. General Office of the State Council of China. Notice on Implementing a New Round of Rural Power Grid Transformation and Upgrading during the 13th Five-Year Plan Period forwarded by General Office of the State Council from National Development and Reform Commission's. Available online: http: / www.gov. cn/zhengce/content/2016-02/22/content_5044629.htm (accessed on 8 March 2018). 
82. Shan, M.; Wang, P.S.; Li, J.R.; Yue, G.; Yang, Y. Energy and environment in Chinese rural buildings: Situations, challenges, and intervention strategies. Build. Environ. 2015, 91, 271-282. [CrossRef]

83. Ministry of Housing and Urban-Rural Development. Notice of the Ministry of Housing and Urban-Rural Development on Issuing the "13th Five-Year Plan" for Building Energy Conservation and Green Building Development. Available online: http:/ /www.mohurd.gov.cn/wjfb/201703/t20170314_230978.html (accessed on 10 March 2018).

84. Lu, S.L.; Feng, W.; Kong, X.F.; Wu, Y. Analysis and case studies of residential heat metering and energy-efficiency retrofits in China's northern heating region. Renew. Sustain. Energy Rev. 2014, 38, 765-774. [CrossRef]

85. Hebei Provincial Department of Agriculture; Hebei Provincial Government Office of Rural Work. Notice on Prompt Start of Efficient and Clean Burning Stoves Retrofit in 2016. Available online: http:/ / www.heagri. gov.cn/article/tzgg/201603/20160300000994.shtml (accessed on 20 October 2017).

86. Ministry of Finance, Ministry of Commerce of PRC. Notice of the Ministry of Finance and the Ministry of Commerce on Printing and Distributing the Work Plan for Promoting Household Appliances to the Countryside. Available online: http:/ / www.mofcom.gov.cn/aarticle/h/redht/200810/20081005834532. html (accessed on 5 December 2017).

87. Yoldaş, Y.; Önen, A.; Muyeen, S.M.; Vasilakos, A.V.; Alan, I. Enhancing smart grid with microgrids: Challenges and opportunities. Renew. Sustain. Energy Rev. 2017, 72, 205-214. [CrossRef]

88. Zhu, X.; Han, X.Q.; Qin, W.P.; Wang, P. Past, today and future development of micro-grids in China. Renew. Sustain. Energy Rev. 2015, 42, 1453-1463. [CrossRef]

89. Granell, C.; Havlik, D.; Schade, S.; Sabeur, Z.; Delaney, C.; Pielorzb, J.; Usländer, T.; Mazzetti, P.; Schleidt, K.; Kobernus, M.; et al. Future Internet technologies for environmental applications. Environ. Model. Softw. 2016, 78, 1-15. [CrossRef]

90. United Nations. Report of the World Commission on Environment and Development: Our Common Future. Available online: http:/ / www.un-documents.net/wced-ocf.htm (accessed on 5 December 2017).

91. United Nations. 21 Agenda. 2004. Available online: http://www.un.org/chinese/events/wssd/agenda21. htm (accessed on 1 March 2018).

92. National Planning Commission of China. China's Agenda 21; China Environmental Science Press: Beijing, China, 1994.

93. Ni, W.D.; Johansson Thomas, B. Energy for sustainable development in China. Energy Policy 2004, 32, 1225-1229.

94. National Development and Reform Commission. China Submits Nationally Determined Contributions to Address Climate Change. Available online: http:/ / www.ndrc.gov.cn/xwzx/xwfb/201506/t20150630_ 710204.html (accessed on October 2017).

95. Xinhuanet. Firmly March on the Path of Socialism with Chinese Characteristics and Strive to Complete the Building of a Moderately Prosperous Society in all Respects. Report to the Eighteenth National Congress of the Communist Party of China on 8 November 2012. Available online: http:/ / news.xinhuanet.com/18cpcnc/2012-11/17/c_ 113711665.htm (accessed on 5 December 2017).

96. Xinhuanet. Secure a Decisive Victory in Building a Moderately Prosperous Society in All Respects and Strive for the Great Success of Socialism with Chinese Characteristics for a New Era. Report to the Neighteenth National Congress of the Communist Party of China on 18 October 2017. Available online: http:/ / news.xinhuanet. com/politics/19cpcnc/2017-10/27/c_1121867529.htm (accessed on 10 December 2017).

97. CPC Central Committee and State Council. Views of the CPC Central Committee and the State Council on Several Policies for Increasing Farmers' Income. Available online: http:/ /www.gov.cn/test/2005-07/04/ content_11870.htm (accessed on 10 December 2017).

98. National Energy Bureau. Notice of the State Council on Issuing the "12th Five-Year Plan" for Energy Development. Available online: http://www.nea.gov.cn/2013-01/28/c_132132808.htm (accessed on 10 December 2017).

99. National Development and Reform Commission. Notice of the National Development and Reform Commission and National Energy Bureau on Issuing the "13th Five-Year Plan" for Energy Development. Available online: http://www.ndrc.gov.cn/zcfb/zcfbtz/201701/t20170117_835278.html (accessed on 18 December 2017). 
100. Fu, F.; Ma, L.W.; Li, Z.; Plenske, K.R. The implications of China's investment-driven economy on its energy consumption and carbon emissions. Energy Convers. Manag. 2014, 85, 573-580. [CrossRef]

101. Karlsson, N.P.E.; Halila, F.; Mattsson, M.; Hoveskog, M. Success factors for agricultural biogas production in Sweden: A case study of business model innovation. J. Clean. Prod. 2017, 142, 2925-2934. [CrossRef]

102. Beermann, J.; Tews, K. Decentralised laboratories in the German energy transition. Why local renewable energy initiatives must reinvent themselves. J. Clean. Prod. 2017, 169, 125-134. [CrossRef]

103. Kirchhoff, H.; Kebir, N.; Neumann, K.; Heller, W.; Strunz, K. Developing mutual success factors and their application to swarm electrification: Microgrids with $100 \%$ renewable energies in the Global South and Germany. J. Clean. Prod. 2016, 128, 190-200. [CrossRef]

(C) 2018 by the authors. Licensee MDPI, Basel, Switzerland. This article is an open access article distributed under the terms and conditions of the Creative Commons Attribution (CC BY) license (http://creativecommons.org/licenses/by/4.0/). 